Acta Horticulturae et Regiotecturae 2

Nitra, Slovaca Universitas Agriculturae Nitriae, 2019, pp. 65-70

\title{
EFFECTS OF BIOCHAR AND ITS REAPPLICATION ON SOIL PH AND SORPTION PROPERTIES OF SILT LOAM HAPLIC LUVISOL
}

\author{
Martin JURIGA*, Vladimír ŠIMANSKÝ \\ Slovak University of Agriculture in Nitra, Slovak Republic
}

\begin{abstract}
In this paper we investigate the effects of biochar alone and its reapplication and combination with $\mathrm{N}$-fertilizer (1) on the soil pH, and (2) sorption parameters. The soil samples were taken during growing period in 2018 from plots with different biochar (first application in $2014-\mathrm{A}$, reapplication in 2018 - B) at application rates: 0 t.ha $^{-1}$ (B0 control), 10 t.ha $^{-1}$ (B10) and 20 t.ha ${ }^{-1}$ (B20) and different nitrogen fertilization: N0 (no nitrogen) and N40 $\left(40 \mathrm{~kg} \mathrm{ha}^{-1}\right)$. Our results showed that the first application of biochar at the rate of 20 t.ha $^{-1}$ (B2OA) without $\mathrm{N}$-fertilizer significantly increased the values of soil $\mathrm{pH}$ in $\mathrm{H}_{2} \mathrm{O}$, soil pH in $\mathrm{KCl}$, the sum of base cations (SBC) and cation exchange capacity (CEC) compared to control (B0). Similar effects were observed also after reapplication of biochar (B10B). All investigated parameters in fertilized control treatment (BON40) were worst and the first application, as well as the reapplication of biochar with $\mathrm{N}$, caused significant increase of soil $\mathrm{pH}$ in $\mathrm{H}_{2} \mathrm{O}$, soil $\mathrm{pH}$ in $\mathrm{KCl}, \mathrm{SBC}, \mathrm{CEC}, \mathrm{BS}$ and decrease of hydrolytic acidity.
\end{abstract}

Keywords: soil acidity, cation exchange capacity, base saturation, biochar, fertilization

Soil acidity presents a world-wide problem as it reduces the soil fertility. Acidification is a slow, continual and natural process that considerably affects the sustainability of agriculture (Rengel, 2002; Guo et al., 2010). Approximately $50 \%$ of world's arable land is considered acidic (Kochian et al., 2015). Acidic soil is unsuitable for most field crops with the exception of some. Soil pH value expresses the degree of acidity and alkalinity of soil. Soil sorption is arguably the most important physico-chemical process that ensures the retention of nutrients, heavy metals and other chemical substances in soil (Thompson et al., 2012). According to Essington (2004), the ability of soil to retain cations increases with increasing $\mathrm{pH}$. This is supported by Zhang et al. (2015) who claim that $\mathrm{pH}$ value and soil organic carbon content (SOC) are the main factors influencing the content of basic cations exchange. In the acidic soils the total content of cations is considerably lower. In addition, cation exchange capacity (CEC) is dependent on soil organic matter content (SOM). In general, SOM has a high content of basic cations exchange due to the presence of functional groups on the surface area of its particles.

According to Dai et al. (2017), application of biochar, to raise soil $\mathrm{pH}$, could present an acceptable solution to high soil acidity. There is a consensus that biochar application raises the $\mathrm{pH}$ in acidic soils (Juriga and Šimanský 2018; Šimanský et al., 2018). Adding biochar into the soil could prove to be a valuable instrument in the efforts to increase the soil fertility and its use is deemed an important to counter the risks of soil acidification (Dai et al., 2017). Biochar represents a solid carbon-based product, which is produced during the thermal decomposition of different organic materials, under conditions with limited access to oxygen (Lorenz and Lal, 2014). Biochar has specific properties which mainly depend on the type of material used for its production and producing conditions. Through its properties, biochar can influence various soil properties, such as: soil organic carbon content (Šimanský et al., 2018a; Juriga et al., 2018), aggregate stability (Šimanský et al., 2016), bulk density, soil pH, CEC, electric conductivity (Chintala et al., 2014), soil biota (Lehmann et al., 2011), etc.

There are several mechanisms that enable biochar to suppress the acidity of the soil and help to increase the soil $\mathrm{pH}$ (Dai et al., 2017). Biochar's specific properties reduce the soil acidity through its alkaline nature and high buffer capacity. The ability of biochar particles to absorb the $\mathrm{H}^{+}$ ions, as well as decarboxylation processes, are probably the main factors in soil acidity neutralization (Wang, Li and Liang, 2013). The biochar particles in soil are subject to gradual oxidation which leads to the production of functional groups containing oxygen (Hansen et al., 2016). During pyrolysis, the cations such as: $\mathrm{Ca}, \mathrm{Mg}, \mathrm{K}$ and $\mathrm{Si}$ which are contained in the organic materials used in bio-fuel production, form carbonates or oxides (Zong et al., 2018). When we apply biochar to the acidic soil, these carbonates and oxides react with $\mathrm{H}^{+}$and $\mathrm{Al}^{+3}$ ions and thus increase the $\mathrm{pH}$ and decrease the soil's acidity (Novak et al., 2009).Yuan, Xu and Zhang (2011) have shown that functional groups such as $\mathrm{COO}-$ and $\mathrm{O}-$ can also react with $\mathrm{H}^{+}$and $\mathrm{Al}^{+3}$ ions in the soil and significantly contribute to the alkalinity of soil. The range of changes in $\mathrm{pH}$ and acidity depends on biochar properties. As stated by Fidel et al. (2017), biochar alkalinity strongly correlates with the content of basic cations in

Contact address: Ing. Martin Juriga, Slovak University of Agriculture in Nitra, Faculty of Agrobiology and Food Resources, Department of Soil Science, 94976 Nitra, Tr. Andreja Hlinku 2, Slovak Republic, e-mail: xjuriga@uniag.sk 
the soil. Ahmad et al. (2014) refers to surface absorption and electrostatic interactions as the main mechanisms in interaction between biochar particles and particles of organic matter. A large surface area, a high number of functional groups, a negative charge and also a porous structure have major functions in these processes (Dai et al., 2017; Yang, Ying and Kookana, 2009).

Based on the above context, we expect that application of biochar, biochar with $\mathrm{N}$ fertilizer and biochar reapplication could increase soil $\mathrm{pH}$ and improve soil sorptive properties in a silt loam Haplic Luvisol. Therefore, the aim of this study is to evaluate the effects of biochar, biochar with $\mathrm{N}$ fertilization and biochar reapplication on changes of soil $\mathrm{pH}$ and soil sorption parameters.

\section{Material and methods}

The study was conducted at the experimental station of Slovak University of Agriculture in Nitra (Dolná Malanta, $48^{\circ} 10^{\prime} 00.0^{\prime \prime} \mathrm{N} 18^{\circ} 09^{\prime} 00.0^{\prime \prime} \mathrm{E}$ ) during the growing period of spring barley in 2018. The station is situated approximately $4 \mathrm{~km}$ from Nitra in Žitava highlands, with an altitude of $175 \mathrm{~m}$ a. s. I. The soil is classified as silt loam Haplic Luvisol and on average it contained $9.13 \mathrm{~g} . \mathrm{kg}^{-1}$ of soil organic carbon, while the average soil pH was 5.71 (Šimanský et al., 2018a). The studied area has a planar character with a slight south western facing of the slope. Climate is warm and dry with an average annual air temperature of about $9.5^{\circ} \mathrm{C}$ and average annual sum of precipitation $540 \mathrm{~mm}$.

The experiment was established in 2014, before the sowing of spring barley. This is when biochar was applied for the first time at the rate of 10 and 20 t.ha $^{-1}$. From the beginning of the experiment until now, the following crops were grown on the field in the years 2014, 2015, 2016, 2017 and 2018, respectively: spring barley, corn, spring wheat, corn and spring barley. Before the sowing of spring barley, biochar was reapplied at the same rates in 2018. The overview of the treatments is shown in Table 1. Biochar used in this experiment was produced from grains husks and paper, at the temperature of $500{ }^{\circ} \mathrm{C}$. Its basic composition and properties are given in Table 2. The nitrogen fertilizer - LAD 27 is used every year at different rates based on the crop's needs. $\mathrm{N}$ fertilizer was used at the rates of $40 \mathrm{~kg} \cdot \mathrm{N}^{-1} \cdot \mathrm{ha}^{-1}$ in 2018.
Table 2 The basic chemical composition and properties of applied biochar

\begin{tabular}{|l|c|}
\hline Total C & $531 \mathrm{~g}^{\mathrm{kg}}{ }^{-1}$ \\
\hline Total N & $14 \mathrm{~g} \cdot \mathrm{kg}^{-1}$ \\
\hline $\mathbf{C a}$ & $57 \mathrm{~g} \cdot \mathrm{kg}^{-1}$ \\
\hline $\mathbf{M g}$ & $3.9 \mathrm{~g} \cdot \mathrm{kg}^{-1}$ \\
\hline $\mathbf{K}$ & $15 \mathrm{~g} \cdot \mathrm{kg}^{-1}$ \\
\hline $\mathbf{N a}$ & $0.7 \mathrm{~g} \cdot \mathrm{kg}^{-1}$ \\
\hline Ash & $383 \mathrm{~g} \cdot \mathrm{kg}^{-1}$ \\
\hline pH in $\mathbf{H}_{\mathbf{2}} \mathbf{O}$ & 8.8 \\
\hline Size of biochar & $1-5 \mathrm{~mm}$ \\
\hline
\end{tabular}

The soil samples were collected at regular monthly intervals from all treatments during the growing season of spring barley in 2018 (from April to July). The sampling was carried out from the depth of $0-0.30 \mathrm{~m}$. Subsequently, parts of plants were removed, and the samples were transported to the laboratory where they were dried. Finally, the following parameters in the soil samples were determined:

- soil $\mathrm{pH}$ in $\mathrm{H}_{2} \mathrm{O}$ (ratio soil to distilled water, $1: 2.5$ ) and soil $\mathrm{pH}$ in $1 \mathrm{~mol} . \mathrm{dm}^{-3} \mathrm{KCl}$ (ratio soil to $\mathrm{KCl}, 1: 2.5$ ) potentiometrically (Fiala et al., 1999);

- hydrolytic acidity $(H)$, the sum of basic cations (SBC) according to Kappen method (Fiala et al.,1999);

- cation exchange capacity (CEC) and base saturation (BS) according to equations 1 and 2:

$$
\begin{aligned}
& C E C=H+S B C \\
& B S=\frac{S B C}{C E C} \cdot 100
\end{aligned}
$$

Average values of soil $\mathrm{pH}$ and soil sorptive parameters by ANOVA single-factor analysis (Statgraphic Centurion XV Program I.) were determined. The LSD test with the level of significance $P<0.05$ was used to compare the effects of biochar, biochar with nitrogen fertilizer and biochar reapplication.

\begin{tabular}{|c|c|c|c|}
\hline BO & without biochar & control & \multirow{5}{*}{ without $\mathrm{N}$ fertilittzer } \\
\hline B10A & 10 t.ha $^{-1}$ of biochar & \multirow{2}{*}{ first biochar application (2014) } & \\
\hline B20A & 20 t.ha $^{-1}$ of biochar & & \\
\hline В10B & 10 t.ha ${ }^{-1}$ of biochar & \multirow{2}{*}{ biochar reapplication (2018) } & \\
\hline B20B & 20 t.ha $^{-1}$ of biochar & & \\
\hline BON40 & without biochar & $\mathrm{N}$ treatment & \multirow{5}{*}{ with $\mathrm{N}$ fertilizer } \\
\hline B10N40A & 10 t.ha $^{-1}$ of biochar & \multirow{2}{*}{ first biochar application (2014) } & \\
\hline B20N40A & 20 t.ha $^{-1}$ of biochar & & \\
\hline B10N40B & 10 t.ha ${ }^{-1}$ of biochar & \multirow{2}{*}{ biochar reapplication (2018) } & \\
\hline B20N40B & 20 t.ha ${ }^{-1}$ of biochar & & \\
\hline
\end{tabular}

Table 1 The overview of evaluated treatments 


\section{Results and discussion}

The biochar application can be beneficial for soil $\mathrm{pH}$ enhancement (e. g. Chintala et al., 2013; Obia et al., 2015; Horák et al., 2017; Teutscherova et al., 2017; Šimanský et al., 2018) as confirmed by our data. As shown in Fig. 1, in the case of treatments with the first biochar application without a nitrogen fertilizer, the statistically significant effect on soil $\mathrm{pH}$ increase was recorded in B20A treatment. Consequently, the soil $\mathrm{pH}$ in $\mathrm{H}_{2} \mathrm{O}$ significantly increased from 6.06 (B0) to $6.47(\mathrm{~B} 20 \mathrm{~A})$ and $\mathrm{pH}$ in $\mathrm{KCl}$ from 5.66 (B0) to 6.0 (B20A). However, the addition of 10 t.ha $^{-1}$ of biochar did not have significant influence on pH changes. Zong et al., (2018) also confirmed that higher rates of biochar are more beneficial, stating that the volume of biochar added to the soil is crucial when trying to affect the $\mathrm{pH}$ values and acidity of the soil. Biochar reapplication had a statistically significant effect on the $\mathrm{pH}$ values in treatments at both rates (B10B and $\mathrm{B} 20 \mathrm{~B}$ ). The higher values in $\mathrm{B} 20 \mathrm{~B}$ treatment: $6.71\left(\mathrm{pH}\right.$ in $\left.\mathrm{H}_{2} \mathrm{O}\right)$ and 6.23 ( $\mathrm{pH}$ in $\mathrm{KCl}$ ) than in $\mathrm{B} 10 \mathrm{~B}$ treatment: 6.47 $\left(\mathrm{pH}\right.$ in $\mathrm{H}_{2} \mathrm{O}$ ) and $6.0(\mathrm{pH}$ in $\mathrm{KCl}$ ) were measured. The same values $-\mathrm{pH}$ in $\mathrm{H}_{2} \mathrm{O}$ (6.47) and $\mathrm{pH}$ in $\mathrm{KCl}$ (6.0) were found in B20A and B10B treatments. For example, Cornelissen et al. (2018) also observed a significant increase in $\mathrm{pH}$ soon after the application of biochar

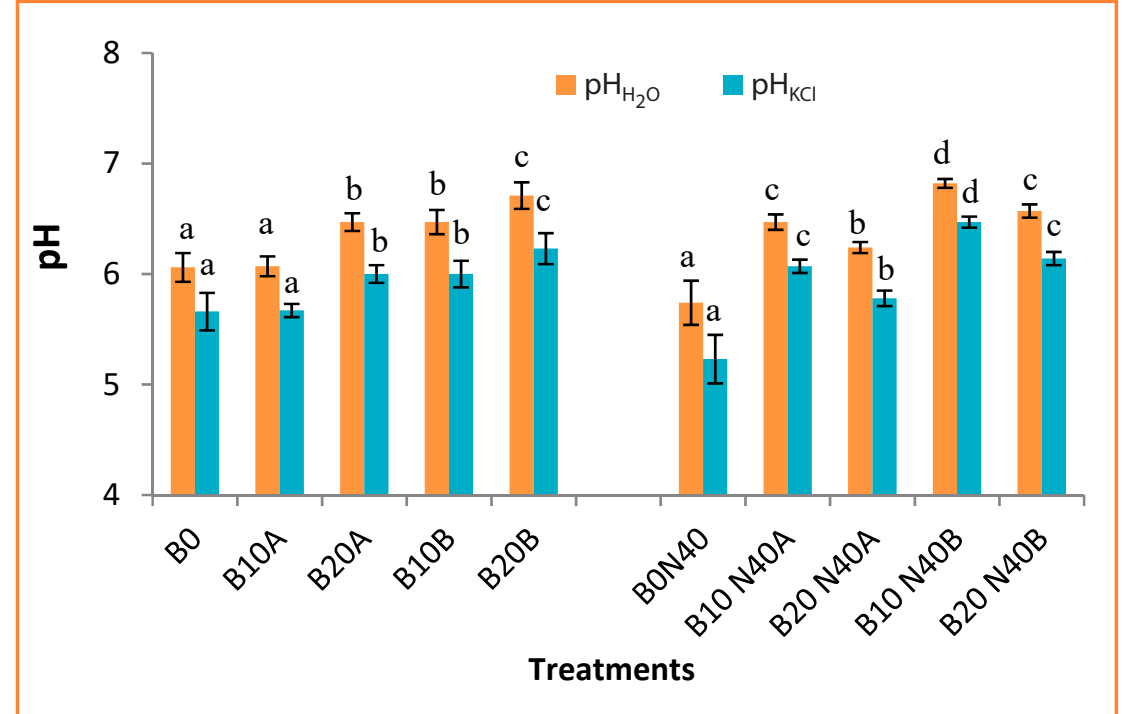

Figure 1 Statistical evaluation of soil $\mathrm{pH}$

the individual letters $(a, b, c, d)$ in columns (at the same colour) represent the statistical significance $(P<0.05)$ of the application of biochar, biochar with $\mathrm{N}$ or biochar reapplication

into the soil, while $\mathrm{pH}$ values gradually decreased due to the weakening of the biochar's liming effect in the following years. According to Cornelissen et al. (2018) this decrease could be caused by the gradual leaching of alkaline compounds from biochar. They consider effective to apply biochar to the soil every three years to maintain the neutralizing effect. Castaldi et al. (2011) stated that the ability of biochar to affect the soil $\mathrm{pH}$ decreased as soon as 14 months after the application. It was proven that different kinds of biochar affect the soil $\mathrm{pH}$ differently. This depends on the specific biochar properties, mainly on the used materials and production temperature (Keiluweit, Nico and Kleber, 2010; Ahmad et al., 2014; Masud, Li and Xu, 2014). Alkaline properties of biochar tend to increase with the pyrolysis temperature (Yuan, Xu and Zhang, 2011). In our case, the best results were recorded in the treatment with biochar reapplication at the rate of 20 t.ha $^{-1}$ which confirmed the data of abovementioned authors (e.g. Castaldi et al., 2011; Cornelissen et al., 2018).

Since the biochar is alkaline, it might increase of soil $\mathrm{pH}$, but this effect could be softened with adding

Table 3 Statistical evaluation of soil sorption parameters

\begin{tabular}{|c|c|c|c|c|}
\hline \multirow[t]{2}{*}{ Treatments } & $\mathbf{H}$ & SBC & CEC & \multirow{2}{*}{$\begin{array}{c}\text { BS } \\
\%\end{array}$} \\
\hline & \multicolumn{3}{|c|}{ mmol.kg ${ }^{-1}$} & \\
\hline BO & $16.65 \pm 3.00^{b c}$ & $137.28 \pm 8.29^{a}$ & $153.93 \pm 6.45^{\mathrm{a}}$ & $89.14 \pm 2.24^{\mathrm{ab}}$ \\
\hline B10A & $19.81 \pm 3.52^{c}$ & $140.34 \pm 12.30^{\mathrm{ab}}$ & $160.15 \pm 10.40^{\mathrm{ab}}$ & $87.55 \pm 2.51^{\mathrm{a}}$ \\
\hline B20A & $14.17 \pm 1.72^{b}$ & $164.06 \pm 14.29^{b}$ & $177.70 \pm 13.33^{b}$ & $91.47 \pm 1.31^{b c}$ \\
\hline B10B & $15.20 \pm 3.01^{b}$ & $163.80 \pm 8.97^{b}$ & $179.25 \pm 6.29^{b}$ & $91.99 \pm 1.92^{b c}$ \\
\hline B20B & $11.47 \pm 2.46^{\mathrm{a}}$ & $194.66 \pm 30.86^{c}$ & $206.12 \pm 29.43^{c}$ & $94.29 \pm 1.74^{c}$ \\
\hline BON40 & $27.53 \pm 1.11^{d}$ & $117.90 \pm 10.67^{\mathrm{a}}$ & $145.43 \pm 10.58^{\mathrm{a}}$ & $80.99 \pm 1.60^{a}$ \\
\hline B10 N40A & $14.10 \pm 3.08^{b}$ & $167.63 \pm 6.68^{b}$ & $181.73 \pm 4.53^{\mathrm{bc}}$ & $92.22 \pm 1.80^{\mathrm{b}}$ \\
\hline B20 N40A & $20.22 \pm 1.77^{c}$ & $152.59 \pm 7.94^{b}$ & $172.80 \pm 8.75^{b}$ & $88.30 \pm 0.87^{b}$ \\
\hline B10 N40B & $6.29 \pm 2.89^{\mathrm{a}}$ & $226.28 \pm 6.03^{d}$ & $232.57 \pm 7.67^{d}$ & $97.32 \pm 1.19^{c}$ \\
\hline B20 N40B & $13.57 \pm 1.67^{b}$ & $195.68 \pm 20.88^{c}$ & $202.49 \pm 26.86^{c}$ & $97.01 \pm 9.39^{c}$ \\
\hline
\end{tabular}

the individual letters $(a, b, c, d)$ in lines represent the statistical significance $(P<0.05)$ of the effect of the application of biochar, biochar with $\mathrm{N}$ or biochar reapplication, $\mathrm{H}$ - hydrolytic acidity, SBC - the sum of basic cations, CEC - cation exchange capacity, BS - base saturation 
of nitrogen fertilization. Therefore, we evaluated also the changes in soil $\mathrm{pH}$ under treatments with $\mathrm{N}$ fertilization (Fig. 1). The lowest values of $\mathrm{pH}$ in $\mathrm{H}_{2} \mathrm{O}$ and $\mathrm{pH}$ in $\mathrm{KCl}$ in treatments with $\mathrm{N}$ fertilization were measured in B0N40 treatment. However, when combined with biochar, the values increased significantly. Yu et al. (2017) compared the effects of $\mathrm{N}$ ammonium fertilizer alone at the rate of $30 \mathrm{~kg} \cdot \mathrm{N}^{-1} \cdot \mathrm{ha}^{-1}$, but also the effect of its combination with 19.5 t.ha $^{-1}$ of biochar. After addition of $\mathrm{N}$ alone, the $\mathrm{pH}$ value was 5.3, while $\mathrm{pH}$ increased from 5.3 to 6.0 after the application of biochar with $\mathrm{N}$. Long-term use of nitrogen fertilizers in the ammonium form can be the reason of soil acidification. This is initiated by the release of $\mathrm{H}^{+}$ions in the process of nitrification (Zhang, Zhang and Li, 2002). In our case, the effect was stronger after adding 10 t.ha $^{-1}$ rather than 20 t.ha $^{-1}$ (Fig. 1). The values of soil $\mathrm{pH}$ in $\mathrm{H}_{2} \mathrm{O}$ in B10N40A, B20N40A, B10N40B and B20N40B treatments were higher than in $\mathrm{B} 0 \mathrm{~N} 40$ by $11.3 \%, 8.0 \%, 15.4 \%$ and by $12.6 \%$, respectively. The values of soil $\mathrm{pH}$ in $\mathrm{KCl}$ in the same treatments were higher by $13.8 \%, 9.5 \%, 19.2 \%$ and $14.8 \%$, respectively.

The average values of the sorption parameters in this study are shown in Table 3. We did not find any significant effects on hydrolytic acidity $(H)$ in treatments with initial added biochar without $\mathrm{N}$, however the values of sum of basic cations (SBC) and cation exchange capacity (CEC) in B20A treatment significantly increased by $16.3 \%$ and $13.4 \%$ compared to B0 treatment. On the other hand, B10A treatment showed no significant changes. In several studies (e.g. Wang, Li and Liang, 2013) the positive impact of biochar on the content of CEC has been demonstrated. The biochar effect increased along with its applied rate. The re-addition of biochar without $\mathrm{N}$ with the lower rate also significantly increased the SBC by $16.2 \%$ and CEC by $14.13 \%$ compared to B0 treatment (Table 3). Furthermore, the reapplication of biochar with higher rate suppressed $\mathrm{H}$ from $16.65 \mathrm{mmol} . \mathrm{kg}^{-1}$ (B0) to 11.47 (B20B) mmol. $\mathrm{kg}^{-1}$. The SBC value increased from $137.28 \mathrm{mmol} . \mathrm{kg}^{-1}$ (B0) to 194.66 mmol. $\mathrm{kg}^{-1}$ (B20B), CEC value from $153.93 \mathrm{mmol} . \mathrm{kg}^{-1}$ (B0) to $206.12 \mathrm{mmol} . \mathrm{kg}^{-1}$ (B20B) and the BS value from $89 \%(B 0)$ to $94 \%(B 20 B)$. Better results were observed in $B 20 B$ treatment than in B20A. After the biochar adding, it is subject to a whole range of biochemical reactions which can be reflected in a change in its properties over time (Liang et al., 2006). The study of Šimanský et al. (2018) also observed the gradual decline of biochar efficiency during the first three years in this experiment after its first application. The values of SBC, CEC and BS gradually decreased in almost all treatments. According to Ren, Yuan and Sun (2018), some biochar pores are blocked by fine soil particles. These gradually migrate from the outer to the inner portions of the pores. It may result in a reduction in surface area of biochar particles. As a result, it reflects on the suppression of its sorption capacity. In addition, the action of soil organisms can influence the structural properties of biochar, which is also shown to change its sorption capacity. At the same time, Ren, Yuan and Sun (2018) added that the effect of biochar increased in pollutant sorption in the first months after application. However, the biochar surface area gradually decreased over time, thereby decreasing its sorption capacity. It reached the control level within 2.5 years after adding biochar. A similar finding was also found by Martin et al. (2012). Our results showed that the greatest positive effects on the changes of sorption parameters were determined after the biochar reapplication at the rate of 20 t.ha $^{-1}$.

In the case of treatment with $\mathrm{N}$ fertilizer without biochar (BON40), we found the highest value of $\mathrm{H}$ and the lowest values of SBC, CEC and BS. On the other hand, when the $\mathrm{N}$ fertilizer was used in combination with biochar, there was a significant decrease of $\mathrm{H}$ and the SBC, CEC and BS increased in of all four treatments (Table 3). Yu et al. (2017) stated that after the addition of $\mathrm{N}$ with biochar, the content of exchange cations was significantly higher than the addition of $\mathrm{N}$ fertilizer itself. Both rates of originally applied biochar: 10 t.ha $^{-1}$ and 20 t.ha $^{-1}$, respectively decreased $\mathrm{H}$ by $48.8 \%$ and $26.6 \%$, increased SBC by $29.7 \%$ and $22.7 \%$, CEC by $20 \%$, and $15.8 \%$, BS by $12.2 \%$ and $8.3 \%$ compared to B0N40 treatment. After the reapplication of biochar at both rates the $\mathrm{H}$ values dropped from $27.53 \mathrm{mmol} . \mathrm{kg}^{-1}$ (B0N40) to $6.29 \mathrm{mmol}^{\mathrm{kg}} \mathrm{kg}^{-1}$ (B10B40B) and to $13.57 \mathrm{mmol} . \mathrm{kg}^{-1}$ (B20N40B). The SBC values increased by $47.9 \%$ and $39.8 \%$, CEC by $37.5 \%$ and $28.2 \%$,BS by $16.8 \%$ and $16.5 \%$ compared to the BON40 treatment. The most favourable effect of biochar in combination with $\mathrm{N}$ fertilizer was achieved in B10N40B treatment ( $\mathrm{H}$ value - the lowest and opposite the highest values of SBC and CEC).

\section{Conclusion}

The results of our study showed the contrasting effects of the first application and the reapplication of pure biochar and biochar in combination with $\mathrm{N}$ fertilizer on improving of soil $\mathrm{pH}$ and soil sorption parameters.

In the case of the first biochar application without $\mathrm{N}$, in $\mathrm{B} 20 \mathrm{~A}$ treatment we observed significant increase in $\mathrm{pH}$ in $\mathrm{H}_{2} \mathrm{O}, \mathrm{pH}$ in $\mathrm{KCl}, \mathrm{SBC}$ and $\mathrm{CEC}$ by $6.3 \%, 5.7 \%, 16.3 \%$ and $13.4 \%$ compared to $\mathrm{B} 0$ treatment. The reapplication of lower biochar rate had a similar effect to the initial application of higher biochar rate. Additionally, the most beneficial effect in B20B treatment was achieved. We conclude that biochar reapplication at the higher rate had the most significant effect on increase of soil $\mathrm{pH}$.

We found the higher values of $\mathrm{pH}$ in $\mathrm{H}_{2} \mathrm{O}, \mathrm{pH}$ in $\mathrm{KCl}$, $\mathrm{SBC}, \mathrm{CEC}, \mathrm{BS}$ and lower value of $\mathrm{H}$ in B10N40A, B20N40A, $B 10 N 40 B$ and B20N40B treatments compared to B0N40 treatment. In this case, the adding of fresh biochar was also more effective than the first application at the beginning of the experiment. The addition of 10 t.ha $^{-1}$ of fresh biochar had the most beneficial effect on soil $\mathrm{pH}$ and soil sorption parameters.

Based on the results of this study, we conclude that the addition of biochar into soil mainly at a higher rate or in combination with $\mathrm{N}$ every four years could be effective for increase of soil $\mathrm{pH}$ and improve soil sorption properties. In addition, we anticipate that shorter interval between biochar application could be even more advantageous.

\section{Acknowledgements}

This study was supported by Slovak Grand Agency VEGA (Project No. 1/0136/17). 


\section{References}

AHMAD, M. - RAJAPAKSHA, A. U. - LIM, J. E. - ZHANG, M. - BOLAN, N. - MOHAN, D. - VITHANAGE, M. - LEE, S. S. - OK, Y. S. 2014. Biochar as a sorbent for contaminant management in soil and water: A review. In Chemosphere, vol. 99, 2014, pp. 19-33. DOI: 10.1016/j. chemosphere.2013.10.071

CASTALDI, S. - RIONDINO, M. - BARANTI, S. - ESPOSITO, F. R. MARZAIOLI, R. - RUTIGLIANO, F. A. - VACCARI, F. R. - MIGIETTA, F. 2011. Impact of biochar application to a Mediterranean wheat crop on soil microbial acidity and greenhouse gas fluxes. In Chemosphere, vol. 85, 2011, pp. 1461-1471. DOI: 101.1016/j. chemosphere.011.08.031

CHINTALA, R. - MOLLINDE, J. - SCHUMACHER, T. E. - PAPIERNIK, S. K. - MALO, D. D. - KUMAR, S. - GULBRSDSON, D. W. 2013. Nitrate sorption and desorption in biochars from fast pyrolysis. In Microporous and Mesoporous Materials, vol. 179, 2013, pp. 250257. DOI: 10.1016/j.micromeso.2013.05.023

CHINTALA, R. - SCHUMMACHER, T. E. - KUMAR, S. - MALO, D. D. RICE, J. A. - BLEAKLEM, B. - CHILOM, G. - CLAY, D. E. - JULSOIN, J. L. - PAPIERNIK, S. K. - GU, Z. R. 2014. Molecular characterization of biochars and their influence on microbiological properties of soil. In Journal of Hazardous Materials, vol. 279, 2014, pp. 244-256. DOI: 10.1016/j.jhhazmat.2014.06.074

CORNELISSEN, G. - NURIDA, N. L. - HALE, S. E. - MARTINSEN, V. SILVANI, L. - MULDER, J. 2018. Fading positive effect of biochar on crop yield and soil acidity during five growth seasons in an Indonesian Ultisol. In Science of The Total Environment, vol. 634, 2018, pp. 561-568. DOI: j.scietotenv.2018.03.380

DAI, Z. - ZHANG, X. - TANG, C. - MUHAMMAD, N. - WU, J. BROOKES, P. C. - XU, J. 2017. Potential role of biochars in decreasing soil acidification. In Science of The Total Environmental, vol. 581582, 2017, pp. 601-611. DOI: 10.1016/scietotenv.2016.12.169

ESSINGTON, M. E. 2004. Competetive sorption behavior of arsenic, sellenium, coper and lead by soil and biosolid nano and macro colloid particles. In Open Journal of Soil Science, vol. 4, 2004, pp. 293-304. DOI: 10.4236/ojss.2014.49031

FIALA, K. - KOBZA, J. - MATÚŠKOVÁ, L. - BREČKOVÁ, V. MAKOVNÍKOVÁ, J. - BARANČÍKOVÁ, G. - BÚRIK, V. - LITAVEC, T. HOUŠKOVÁ, B. - CHROMANIČOVÁ, A. - VÁRADIOVÁ, D. - PECHOVÁ, B. 1999. Záväzné metódy rozborov pôd. Čiastkový monitorovací systém - PÔDA. 1. vyd. Bratislava : VUPOP, 1999, 142 s. ISBN 80-85361-55-8.

FIDEL, R. B. - LAIRD, D. A. - THOMPSON, M. L. - LAWRENKO, M. 2017. Characterization and quantification of biochar alkalinity In Chemosphere, vol. 167, 2017, pp. 367-373. DOI: 10.1016/j. chemosphere.2016.09.151

GUO, J. H. - LIU, X. J. - ZHANG, Y. - SHEN, J. L. - HAN, W. X. CHRISTIE, P. - GOULDING, K. W. T. - VITOSEK, P. M. 2010. Singificant acidification in major Chinese croplands. In College of Ressources and Evironmental Science, vol. 19, 2010, pp. 1008-1010. DOI: 10.1126/science. 1182570

HANSEN, V. - STÓVER, D. M. - MUKHOLM, L. J. - PELTRE, C. HAGGAARD-NIELSEN, H. - JENSEN, L. S. 2016. The effect of straw and wood gasification biochar on carbon sequestration, selected soil fertility indicators and functional groups in soil: An incubation study. In Geoderma, vol. 269, 2016, pp. 99-107. DOI: j.geoderma.2016.01.033

HORÁK, J. - KONDRLOVÁ, E. - IGAZ, D. - ŠIMANSKÝ, V. - FELBER, R. LUKAC, M. - BALASHOV, E. V. - BUCHKINA, N. P. - RIZHIYA, E. Y. JANKOWSKI, M. 2017. Biochar and biocharwith $\mathrm{N}$ fertilizeraffectsoil $\mathrm{N}_{2} \mathrm{O}$ emission in HaplicLuvisol. In Biologia, vol. 72, 2017, pp. 9951001. DOI: 10.1515/biolog-2017-0109
JURIGA, M. - ŠIMANSKÝ, V. - HORÁK, J. - KONDRLOVÁ, E. - IGAZ, D. POLLÁKOVÁ, N. - BUCHKINA, N. P. - BALASHOV, E. 2018. The effect of different rates of biochar and biochar in combination with $\mathrm{N}$ fertilizer on the parameters of soil organic matter and soil structure. In Journal of Ecological Engineering, vol. 19, 2018, pp. 153-161. DOI: 10.129/22998993/92894

JURIGA, M. - ŠIMANSKÝ, V. 2018. Effect of biochar on soil structurereview. In Acta fytotechnica et zootechnica, vol. 19, 2018, pp. 11-19. DOI: 10.15414/afz.2018.21.01.11-19

KEILUWEIT, M. - NICO, P. S. - KLEBER, M. 2010. Dynamic molecular structure of plant biomaso-derived black carbon (biochar). In Environmental Science and Technol., vol. 44, 2010, pp. 1247-1253. DOI: 10.1021/es9031419

KOCHIAN, L. V. - PIŇEREROS, M. A. - LIU, J. - MAGALHAES, I. V. 2015. Plant adaptation to acid soils: The molecular basis of crop aluminium resistance. In Annual Review of Plant Biology, vol. 66, 2015, pp. 571-598. DOI: 10.1146/annurev-arplant-043014

LEHMANN, J. - RILLING, M. C. - THIES, J. - MASIELLO, C. A. HOCKADAY, W. C. - CROWLEY, D. 2011. Biochar affect on soil biota A review. In Soil Biology and Biochemistry, vol. 43, 2011, pp. 1812 1836. DOI: 10.1016/j.soilbio.2011.04.022

LIANG, B. - LEHMANN, J. - SOLOMON, D. - KINYANG, J. - GROSSMAN J. - O'NEILL, B. - SKIEMSTAD, J. O. - LUZAO, T. J. - PETERSEN, J. NEVES, E. G. 2006. Black carbon increases cation exchange capacity in soil. In Soil Sciency Society of American Journal, vol. 70, 2006, pp. 35-44.

LORENZ, K. - LAL, R. 2014. Biochar application to soil for climate change mitigation by soil organic carbon sequestration. In Journal of Plant Nutrition and Soil Science, vol. 177, 2014, pp. 651-670. DOI: 10.1002/jpnl.201400058

MARTIN, S. M. - KOOKANA, R. S. - ZWEITEN, L. V. - KRULL, E. 2012. Marked changes in herbicide sorption desorption upon ageing of biochars in soils. In Journal of Hazardous Materials, vol. 231-232, 2012, pp. 70-78. DOI: 10.1016/j.jhazmat.2012.06.040

MASUD, M. M. - LI, J.Y. - XU, R. K. 2014. Use of alkaline slag and crop residue biochars to promote base saturation and reduce acidity of an acidic Ultisoil. In Pedosphere, vol. 21, 2014, pp. 791-798. DOI: 10.1016/S1002-0160(14)60066-7

NOVAK, J. M. - LIMA, I. - XING, B. - GSKIN, J. W. - STEINER, CH. DAS, K. C. - AHMEDNA, M. - REHRAH, D. - WATTS, D. W. - BUSSCHER, W. J. - SCHOMBERG, H. 2009. Characterization of designer biochar produced at different temperatures and their effect on a Loamy sand. In Annals of Environmental Science, vol. 3, 2009, pp. 195-206. ISSN 1939-2621.

OBIA, A. - CORNELISSEN, G. - MOLDE, J. - DÖRSH, P. 2015. Effect of soil $\mathrm{pH}$ increase by biochar on $\mathrm{NO}, \mathrm{H}_{2} \mathrm{O}$ and $\mathrm{N}_{2}$ production during denitrification in acid soils. In Research Article, vol. 10, 2015. DOI: 10.1371/journal.pone.01387

REN, X. YUAN, X. - SUN, W. 2018. Dynamic changes in atrazine and phenauthrene sorption behaviors during the aging of biochar in soils. In Environmental Science and Pollution Research, vol. 25, 2018, pp. 81-90. DOI: 10.1007/s11356

RENGEL, Z. 2002. Handbook of planth growth, pH as the master variable. New York : Marcel Dekter, 2002, 446 p. ISBN 9780824707613

ŠIMANSKÝ, V. - HORÁK, J. - IGAZ, D. - BALASHOV, E. - JONCZAK, J. 2018. Biochar and biochar with $N$ fertilizer as a potential tool for improving soil sorption of nutrients. In Journal of Soils and Sediments, vol. 18, 2018, pp. 1432-1440. DOI: 10.1007/ s11368-017-1886-y

ŠIMANSKÝ, V. - HORÁK, J. - IGAZ, D. - JONCZAK, J. - MARKIEWICZ, M. - FELBER, R. - RIZHIYA, E. Y. - LUKAC, M. 2016. How dose of biochar and biochar with nitrogen can improve the parameters of soil organic matter and soil structure? In Biologia, vol. 71, 2016, no. 9, pp. 989-995. DOI: 10.1515/biolog-2016-0122 
ŠIMANSKÝ, V. - IGAZ, D. - HORÁK, J. - ŠURDA, P. - KOLENČÍK, M. - BUCHKINA, N. P. - UZAROWICZ, Ł. - JURIGA, M. - ŠRANK D. - PAUKOVÁ, Ž. 2018a. Response of soil organic carbon and water-stable aggregates to different biochar treatments including nitrogen fertilizer. In Journal Hydrology and Hydromechanics, vol. 66, 2018, pp. 429-436. DOI: 10.2478/john-2018-0033

TEUTSCHEROVA, N. - VAZGUEZ, E. - SANTANA, D. - NAVAS, M. MASAGUER, M. B. 2017. In fluence of pruning waste compost maturity and biochars on carbon dynamics in acid soil: Incubation study. In European Journal of Soil Biology, vol. 78, 2017, pp. 66-74. DOI: 10.1016/j.ejsobi.2016.12.001

THOMPSON, R. C. - BAKIR, A. - STEVEN, J. - RICHARD, C. 2012. Competetive ofpersistant organic pollutants into microplastic in the marine environment. In Marine Pollution Bulletin, vol. 64, 2012, pp. 2782-2789. DOI: 10.1016/j.marpollbul.2012.09.010

WANG, B. - LI, C. - LIANG, H. 2013. Bioleaching of heavy metal from woody biochar aging Acidithio bacillusferrooxidans and activation for adsorption. In Bioresource Technology, vol. 146, 2013, pp. 803806. DOI: 10.1016/j.biotech.2013.08.020

YANG, X. - YING, G. G. - KOOKANA, R. S. 2009. Reduced plant uptake of pesticides with biochar additions to soil. In Chemosphere, vol. 76, 2009, pp. 665-667. DOl: 10.1016/j.chemosphere.2009.04.001

YU, L. - LU, X. - YU, M. - XU, J. 2017. Combined application of biochar and nitrogen fertilizer benefits nitrogen retention in the rhizosphere of soybean by increasing microbial biomass but not altering microbial community structure. In Science of the Total Environment, vol. 187, 2017, pp. 640-641. DOI: 10.1016/j. scitoenv.2018.06.018

YUAN, J. H. - XU, R. K. - ZHANG, H. 2011. The forms of alkalis in the biochars produced from crop residues at different temperatures. In Bioresource Technology, vol. 102, 2011, pp. 3488-3497. DOI: j.biotech.2010.11.018

ZHANG, S. - ZHANG, B. - LI, X. 2002. Evolution of soil fertility and fertilizer benefits under different soil types and cropping systems. In Plant Nutrition Fertilization Science, vol. 8, 2002, pp. 9-15.

ZHANG, Y. - YANG, S. - FU, M. M. - CAI, J. P. - ZHANG, Y. Y. - WANG, R. Z. - XU, Z. W. - BAI, Y. T. - JIANG, Y. 2015. Sheep manure application increases soil exchangeable base cations in a semi-arid steppe of Inner Mongolia. In Journal of Arid Land, vol. 7, 2015, pp. 361-369. DOI: 10.1007/s40333015-0004-5

ZONG, Y. - WANG, Y. - SHENG, Y. - WU, C. - LU, S. 2018. Ameliorating soil acidity and physical properties of two contrasting texture Ultisols with wastewater sludge biochar. In Environmental Science and Pollutant Research, vol. 25, 2018, pp. 25726-25733. DOI: 10.1007/s11356-017-9509-0 